\title{
(1)
}

UNIVERSIDAD PERUANA DE CIENCIAS APLICADAS

FACULTAD DE CIENCIAS DE LA SALUD

PROGRAMA ACADÉMICO DE MEDICINA

\section{GUT MICROBIOTA IN HOSPITALIZED CHILDREN UNDER 5 YEARS WITH ACUTE INFECTIVE GASTROENTERITIS CAUSED BY VIRUS OR BACTERIA IN A REGIONAL PERUVIAN HOSPITAL}

\section{TESIS}

Para optar el título profesional de Médico Cirujano

\section{$\operatorname{AUTOR}(\mathbf{E S})$}

Taco Masias, André Alonso (0000-0001-6166-4108)

Fernández Aristi, Augusto Rafael (0000-0003-2952-8223)

\section{$\operatorname{ASESOR}(\mathbf{E S})$}

Juana del Valle Mendoza (0000-0002-6011-5040)

Puyen Guerra, Zully (0000-0002-5068-0986)

Lima, 13 de enero del 2020 
[We dedicate this work to our dear parents, who have always been supporting us unconditionally in good and bad times during the study development, as well as throughout our entire career. Also, we dedicate this work to our teacher and best friend, Javier

Ocampo, who always supported us not only in this part of our career but in many academic and personal aspects. Likewise, we dedicate this work to our couples who arrived at the perfect time to grant us the happiness of enjoying this unforgettable moment of our lives by their side. Last but not least, we dedicate this work to the person who helped us at all times and who has made it possible for this work to be carried out under the best quality standards, thank you very much Dr. Juana del Valle.] 


\section{AKNOWLEDGEMENTS}

We thank our parents, who have been the cornerstone of our work. To the team of the Molecular Biology Laboratory of the Research and Innovation Center of the Universidad Peruana de Ciencias Aplicadas (UPC), the Nutritional Research Institute, the Reference Laboratory of the Direccion Regional de Salud de Cajamarca (DIRESA-Cajamarca) as well as the DIRESA health teamwork staff Cajamarca, Peru.

The study has been supported by the research incentives from the Universidad Peruana de Ciencias Aplicadas, concession number: B-021-2019-UPC, Lima-Peru. 


\section{RESUMEN}

Objetivo el objetivo de este estudio fue describir la prevalencia de 6 géneros de bacterias y 7 Phyla más comunes de la microbiota intestinal (MI) en las muestras fecales de niños menores de 5 años con gastroenteritis infecciosa aguda (GIA) y los patrones clínicos y demográficos poblacionales. Materiales y métodos: se analizó la base de datos de un estudio en donde las muestras fueron obtenidas en niños menores de 5 años hospitalizados con gastroenteritis aguda infecciosa en el "Hospital Docente de Cajamarca" al norte del Perú. Las variables cuantitativas fueron descritas en frecuencias y porcentajes de cada grupo usando el GraphPad Prism3 statistical (Graph Pad Software Inc., San Diego, USA). Resultados: las bacterias aisladas más comunes de la MI fueron Firmicutes (74/117) Bacteriodetes (73/117), Lactobacillus (70/117), Prevotella (67/117) Proteobacterium (63/117), sin tomar en cuenta el agente etiológico responsable de la GIA. Sin embargo, a pesar de la alta prevalencia de Firmicutes, Bacteroidetes, Lactobacillus y Prevotella en todas las muestras, observandose una notable reducción de éstos, especialmente entre los pacientes con una infección bateriana a comparación de las infecciones virales. Los pacientes con lactancia materna exclusiva o mixta denotaron mayor cantidad de bacterias en la MI a comparación de aquellos que recibieron fórmula o no recibieron. Conclusiones A pesar de que en este estudio solo se realizó la detección de algunas bacterias patógenas mediante un método cualitativo, se debe tener en cuenta que existen cambios notorios en la microbiota intestinal, ya sea que se curse con una infección viral o bacteriana

Palabras clave: Microbiota intestinal; gastroenteritis aguda, niños; infección bacteriana; infección viral; infección gastrointestinal. 


\title{
Gut microbiota in hospitalized children under 5 years with acute infective gastroenteritis caused by virus or bacteria in regional Peruvian Hospital
}

\begin{abstract}
Objective: The main objective of this study was to describe the prevalence of 6 common Gut Microbiota (GM) bacterial genera and 7 bacterial phyla in stool samples from children under 5 years of age with acute infective gastroenteritis (AIG), as well as to describe clinical and demographic features from our study population. Materials and methods: we analyzed the data from the database of a previous study, where the samples were obtained from a cross-sectional study in children under 5 years of age, hospitalized due to an acute infective gastroenteritis (AIG) at "Hospital Docente Regional de Cajamarca", in rural Northern Peru. Quantitative variables were described as frequencies and percentages for each group using the GraphPad Prism3 statistical (Graph Pad Software Inc., San Diego, USA). Results: The most commonly isolated bacteria from the GM were Firmicutes (74/117) Bacteriodetes (73/117), Lactobacillus (70/117), Prevotella (67/117), Proteobacterium (63/117), regardless of the etiological agent responsible for the AIG. Interestingly, despite the high prevalence of Firmicutes, Bacteroidetes, Lactobacillus, and Prevotella across all samples, patients with a single bacterial infection, or even bacteria - bacteria coinfections when compared to viral etiologies, showed a visible reduction of these agents. Patients with exclusive or mixed breastfeeding registered the highest amount of gut microbiota bacteria, in contrast to infants who received formula or were not breastfed. Conclusions: Although in this study only the detection of some pathogenic bacteria was performed by a qualitative method, it should be taken into account that there are notable changes in the intestinal microbiota, whether it is carried out with a viral or bacterial infection.
\end{abstract}

Keywords: Intestinal microbiota; acute enteritis; child; bacterial infection; viral infection; gastrointestinal infection. 
TABLE OF CONTENTS

1. INTRODUCTION__ 1

2. MATERIALS AND METHODS___

2.1. PATIENTS AND STUDY DESIGN___

2.2. ETICS STATEMENT _ 3

2.3. SAMPLES 3

2.4. NUCLEI ACID EXTRACTION (ADN)___ 3

2.5. PCR AMPLIFICATIONFOR DETECTION GUT MICROBIOTA___ 3

2.6. DATA ANALYSIS

3. RESULTS 4

4. DISCUSSION — 11

5. CONCLUSION_ 17

6. LIMITATIONS _ 18

7. REFERENCES _ 20 
INDEX OF TABLES

1. Table 1 — 6

2. Table 2 
INDEX OF FIGURES

1. Figure 1

9

2. Figure 2 10 


\section{INTRODUCTION}

Acute infective gastroenteritis (AIG) is a leading cause of mortality in children worldwide [1-3]. AIG accounts for almost 2 million deaths annually in children under 5 years old, with the higher mortality rates concentrated in low-income countries [4,5]. In Peru, a total of 119417 episodes of acute gastroenteritis were reported in 2017, with more than $40 \%$ of cases occurring in children under 5 years old [6].

The high morbidity rates attributed to AIG has encouraged researchers to study the role of the gut microbiota $(\mathrm{GM})$ in the pathogenesis of this disease as well as the therapeutic potential of probiotic bacteria on gastrointestinal infections [7-10]. Current studies have demonstrated the importance of the gut microbiota in maintaining the integrity of the intestinal mucosa [11]. Additionally, GM is responsible for maintaining cell-to-cell junctions of the enterocytes, acting as a defense barrier called "colonization resistance" preventing future viral and bacterial infections [12-14]

In Peru, published information regarding how the interactions between the GM and gastrointestinal pathogens can affect our patients' health is limited. The main objective of this study was to describe the prevalence of 6 common GM bacterial genera and 7 bacterial phyla in stool samples from children under 5 years of age with AIG, using qualitative PCR, as well as to describe clinical data and demographics from our study population. 


\section{MATERIALS AND METHODS}

\subsection{Patients and Study Design}

The data obtained from a cross-sectional study in children under 5 years of age hospitalized due to an acute infective gastroenteritis (AIG) at "Hospital Docente Regional de Cajamarca" in rural Northern Peru [15], was analyzed.

The original study [15], enrolled 117 hospitalized children with AIG from January 2010 to December 2012 for etiological identification in stool samples of the following pathogens: Rotavirus, Adenovirus, Norovirus, C. jejuni, C. coli, Shigella, Salmonella, Enteroaggregative E. coli (EAEC) and Enteropathogenic E. coli (EPEC).

The diagnosis of AIG was defined as diarrhea lasting less than 14 days along with symptoms and signs such as fever, nausea, vomiting, and dehydration based on the guidelines' criteria of the European Society for Pediatric Infectious Diseases. Nutritional status and dehydration status were based on the World Health Organizations' criteria using Z-scores (weight for age).

Qualitative PCR was used to detect 6 common GM bacterial genera including Veillonella, Bacteroides, Lactobacillus, Prevotella, Enterococcus, and Clostriudium; and 7 bacterial phyla such as Bacteriodetes, Fusobacterium, Firmicutes, Actinobacterium, Bifidobacterium, Eubacterium, Proteobacteriu. However, the original study's authors proceeded to describe the frequencies regardless of the bacterial gender or phylum, so the present study took it into account to pursue the main objective. 


\subsection{Ethics Statement}

This study was approved by the Ethics Committee from Universidad Peruana de Ciencias Aplicadas in Lima, Peru. The samples were obtained in the context of the epidemiological surveillance program of the DIRESA - Cajamarca, its use was authorized by that entity and the initial study approved by the ethics committee of the Regional Hospital of Cajamarca with the possibility of carrying out future analyzes with the samples obtained.

\subsection{Samples}

The samples from the original study were stored at $-20^{\circ} \mathrm{C}$ at the laboratory of the Research Center e Innovation for Health Sciences, Universidad Peruana de Ciencias Aplicadas (Lima, Peru).

\subsection{Nucleic Acid extraction (DNA)}

DNA extraction was performed from $200 \mu \mathrm{L}$ of the fecal suspensions using a High Pure PCR template preparation kit (Roche Applied Science, Mannheim, Germany), in accordance with the manufacturer's instructions. Viral RNA/DNA obtained after extraction was eluted in $100 \mu \mathrm{l}$ of nuclease-free water and then processed or stored at $-20^{\circ} \mathrm{C}$ until use.

\subsection{PCR amplification for detection Gut Microbiota}

The analyzed bacteria from the gut microbiota were amplified using DNA extracted from fecal samples and primers previously described by Murri et al [16]. Amplifications were initiated with an incubation at $95^{\circ} \mathrm{C}$ for $2 \mathrm{~min}$, followed by 40 cycles of $95^{\circ} \mathrm{C}$ for $30 \mathrm{~s} ; 58^{\circ} \mathrm{C}$ for $30 \mathrm{~s}$, and $72^{\circ} \mathrm{C}$ for $30 \mathrm{~s}$; with a final extension at $72^{\circ} \mathrm{C}$ for $5 \mathrm{~min}$. Amplified products 
were visualized on a $2.5 \%$ agarose gel containing $3 \mu \mathrm{g} / \mathrm{mL}$ of ethidium bromide in $1 \mathrm{x}$ Trisborate buffer and photographed under violet illumination (UV Transilluminator KODAC LOGIC 1500, New Heaven, USA).

\subsection{Data Analysis}

Quantitative variables were described as frequencies and percentages for each group using the GraphPad Prism3 statistical (Graph Pad Software Inc., San Diego, USA). The frequency distribution was analyzed using $\chi^{2}$-test. The authors could not get more data information such as type of delivery, daycare attendance, vaccines, diet and genetic factors; due to the objective original study did not focus on these variables.

\section{RESULTS}

A total of 117 samples from patients under 5 years old with AIG were analysed via qualitative PCR to detect 6 common GM bacterial genera and 7 bacterial phyla from the gut microbiota (GM). In our study population, infants younger than 12 months-old were the most common age group (36.7\%) followed by children between 18 months and 5 years old $(32.5 \%)$, and finally the remaining was $31 \%$. Mixed breastfeeding was the most frequent practice in $39.3 \%$, followed by exclusive breastfeeding in $29.1 \%$. Clinical symptoms were registered at admission by the attending physicians. Nausea and vomits were the most common complaint in 59\% of patients (69/117), followed closely by fever in $54.7 \%$ (64/117). Mild dehydration was the most common established complication (65.8\%), compared to moderate and severe dehydration with $32.5 \%$ and $1.7 \%$, respectively. 
The distribution of GM of different types of gastrointestinal infection (e.g. virus, bacteria, or their coinfections) were similar or showed no significant differences between them (p>0.05) (Figure 1). However, the most commonly isolated bacteria from the GM were Firmicutes (74/117) Bacteriodetes (73/117), Lactobacillus (70/117), Prevotella (67/117) Proteobacterium (63/117). These 5 bacteria were also the most frequently isolated in all our samples regardless of their etiological agents isolated (Table 1). On the other hand, a visible reduction of Actinobacterium, Enterococcus and Fusobacterium was observed among the patients, especially between those who coursed with a single bacterial infection or even bacteria - bacteria coinfection when compared to viral etiologies. Furthermore, there were viral and bacterial etiologies who showed a greater disruption in the GM, being the most representative of these ones, Adenovirus and Shigella flexneri. The latter being the one showed a low detection of Clostridum (1/31), Veillonella (1/31), Enterococcus (2/31), Actinobacterium spp. (3/31), Bifidobacterium (4/31) and Fusobacterium spp (4/31) and Eubacterium ,compared with Adenovirus who only showed a low detection Bifidobacterium (2/17) and undetectable samples of Fusobacterium (0/17). On this matter, Adenovirus was the only viral etiology who showed a complete absence of detection for one of the GM bacteria. This null detection frequencies's trend has been also observed in other bacterial etiologies, such as Campylobacter jejuni with Enterococcus and Fusobacterium; as well as EAEC with Enterococcus. In addition, we shall stand out that Fusobacterium was the most impaired by all viral etiologies as well as the majority of bacterial agents, followed by

\section{Enterococcus. (Figure 1) (Table 2).}

Finally, gut microbiota variations were also studied among the several types of breastfeeding practices in children with an acute gastroenteritis. Patients with exclusive or mixed breastfeeding registered the higher frequency of the detection of gut microbiota bacteria, in contrast to infants who received formula or were not breastfed $(\mathrm{p}<0.05)($ Figure 2). 
Table 1. Gut Microbiota detected in patients with viral and bacterial acute gastroenteritis $\left(\chi^{2}\right.$ test, $\left.p>0.05\right)$.

\begin{tabular}{|c|c|c|c|c|c|c|c|c|c|c|}
\hline \multirow{3}{*}{ Gut Microbiota } & \multicolumn{3}{|c|}{ VIRUS } & \multicolumn{7}{|c|}{ BACTERIA } \\
\hline & \multirow{2}{*}{$\begin{array}{c}\text { Rotavirus } \\
(\mathrm{n}=42)\end{array}$} & \multirow{2}{*}{$\begin{array}{c}\text { Adenovirus } \\
\quad(\mathrm{n}=17)\end{array}$} & \multirow{2}{*}{$\begin{array}{c}\text { Norovirus } \\
(\mathrm{n}=14)\end{array}$} & \multirow{2}{*}{$\begin{array}{c}\text { C. jejuni } \\
(\mathrm{n}=5)\end{array}$} & \multirow{2}{*}{$\begin{array}{l}\text { C.coli } \\
(\mathrm{n}=13)\end{array}$} & \multirow{2}{*}{$\begin{array}{l}\text { Shiguella } \\
\qquad(\mathrm{n}=31)\end{array}$} & \multirow{2}{*}{$\begin{array}{l}\text { Salmonella } \\
\qquad(\mathrm{n}=3)\end{array}$} & \multicolumn{2}{|c|}{ EAEC } & \multirow{2}{*}{$\begin{array}{c}\text { EPEC } \\
\text { eae } \\
(n=1)\end{array}$} \\
\hline & & & & & & & & $\begin{array}{c}\text { aai } \\
(n=10)\end{array}$ & $\begin{array}{c}\text { aat } \\
(n=1)\end{array}$ & \\
\hline $\begin{array}{l}\text { Firmicutes } \\
\quad(\mathrm{n}=74)\end{array}$ & $37 / 42$ & $16 / 17$ & $9 / 14$ & $4 / 5$ & $12 / 13$ & $29 / 31$ & $3 / 3$ & $10 / 10$ & $1 / 1$ & $1 / 1$ \\
\hline $\begin{array}{l}\text { Bacteriodetes } \\
(\mathrm{n}=73)\end{array}$ & $37 / 42$ & $15 / 17$ & $11 / 14$ & $4 / 5$ & $11 / 13$ & $29 / 31$ & $3 / 3$ & $10 / 10$ & $1 / 1$ & $1 / 1$ \\
\hline $\begin{array}{l}\text { Lactobacillus } \\
\qquad(\mathrm{n}=70)\end{array}$ & $39 / 42$ & $14 / 17$ & $13 / 14$ & $4 / 5$ & $13 / 13$ & $26 / 31$ & $3 / 3$ & $9 / 10$ & $1 / 1$ & $1 / 1$ \\
\hline $\begin{array}{l}\text { Prevotella } \\
\qquad(\mathrm{n}=67)\end{array}$ & $34 / 42$ & $14 / 17$ & $10 / 14$ & $3 / 5$ & $10 / 13$ & $26 / 31$ & $3 / 3$ & $10 / 10$ & $1 / 1$ & $1 / 1$ \\
\hline $\begin{array}{l}\text { Proteobacterium } \\
\qquad(\mathrm{n}=63)\end{array}$ & $35 / 42$ & $12 / 17$ & $11 / 14$ & $4 / 5$ & $13 / 13$ & $24 / 31$ & $3 / 3$ & $8 / 10$ & $1 / 1$ & $1 / 1$ \\
\hline $\begin{array}{l}\text { Bacteriodes } \\
\qquad(\mathrm{n}=52)\end{array}$ & $28 / 42$ & $13 / 17$ & $12 / 14$ & $2 / 5$ & $6 / 13$ & $17 / 31$ & $2 / 3$ & $7 / 10$ & $0 / 1$ & $0 / 1$ \\
\hline $\begin{array}{c}\text { Clostridium } \\
(\mathrm{n}=29)\end{array}$ & $23 / 42$ & $6 / 17$ & $9 / 14$ & $1 / 5$ & $2 / 13$ & $1 / 31$ & $2 / 3$ & $7 / 10$ & $1 / 7$ & $0 / 1$ \\
\hline $\begin{array}{l}\text { Veillonella } \\
\qquad(\mathrm{n}=29)\end{array}$ & $22 / 42$ & $15 / 17$ & $6 / 14$ & $2 / 5$ & $4 / 13$ & $1 / 31$ & $1 / 3$ & $6 / 10$ & $1 / 1$ & $1 / 1$ \\
\hline
\end{tabular}




\begin{tabular}{|c|c|c|c|c|c|c|c|c|c|c|}
\hline $\begin{array}{c}\text { Eubacterium } \\
(\mathrm{n}=24)\end{array}$ & $16 / 42$ & $6 / 17$ & $8 / 14$ & $1 / 5$ & $2 / 13$ & $5 / 31$ & $1 / 3$ & $4 / 10$ & $1 / 1$ & $0 / 1$ \\
\hline $\begin{array}{l}\text { Bifidobacterium } \\
(\mathrm{n}=22)\end{array}$ & $12 / 42$ & $2 / 17$ & $5 / 14$ & $2 / 5$ & $3 / 13$ & $4 / 31$ & $0 / 3$ & $3 / 10$ & $1 / 1$ & $1 / 1$ \\
\hline $\begin{array}{c}\text { Actinobacterium } \\
(\mathrm{n}=20)\end{array}$ & $11 / 42$ & $6 / 17$ & $3 / 14$ & $1 / 5$ & $4 / 13$ & $3 / 31$ & $0 / 3$ & $1 / 10$ & $1 / 1$ & $0 / 1$ \\
\hline $\begin{array}{l}\text { Enterococcus } \\
\qquad(\mathrm{n}=15)\end{array}$ & $5 / 42$ & $4 / 17$ & $2 / 14$ & $0 / 5$ & $3 / 13$ & $2 / 31$ & $1 / 3$ & $0 / 10$ & $0 / 1$ & $1 / 1$ \\
\hline $\begin{array}{c}\text { Fusobacterium } \\
(\mathrm{n}=8)\end{array}$ & $4 / 42$ & $0 / 17$ & $1 / 14$ & $0 / 5$ & $1 / 13$ & $4 / 31$ & $1 / 3$ & $1 / 10$ & $0 / 1$ & $0 / 1$ \\
\hline
\end{tabular}

EAEC aai: Entero-agregattive E. coli aai

EAEC aat: Entero-agregattive E. coli aat

EPEC eae: Entero-patogenic E.coli eae 
Table 2. Gut Microbiota detected in patients with co-infections in acute gastroenteritis $\left(\chi^{2}\right.$ test, $\left.p>0.05\right)$.

\begin{tabular}{|c|c|c|c|c|c|}
\hline Gut Microbiota & $\begin{array}{l}\text { Virus } \\
(n=51)\end{array}$ & $\begin{array}{c}\text { Virus-Virus } \\
(n=13)\end{array}$ & $\begin{array}{l}\text { Virus- Bacteria } \\
\qquad(n=28)\end{array}$ & $\begin{array}{c}\text { Bacteria } \\
(n=18)\end{array}$ & $\begin{array}{c}\text { Bacteria-Bacteria } \\
(n=6)\end{array}$ \\
\hline Firmicutes $(\mathrm{n}=74)$ & $43 / 51$ & $11 / 13$ & $26 / 28$ & $15 / 18$ & $6 / 6$ \\
\hline Bacteriodetes $(\mathrm{n}=73)$ & $42 / 51$ & $12 / 13$ & $25 / 28$ & $16 / 18$ & $6 / 6$ \\
\hline Lactobacillus $(\mathrm{n}=70)$ & $45 / 51$ & $12 / 13$ & $9 / 28$ & $13 / 18$ & $6 / 6$ \\
\hline Prevotella $(\mathrm{n}=67)$ & $39 / 51$ & $11 / 13$ & $25 / 28$ & $13 / 18$ & $5 / 6$ \\
\hline $\begin{array}{l}\text { Proteobacterium } \\
(\mathrm{n}=63)\end{array}$ & $37 / 51$ & $12 / 13$ & $25 / 28$ & $11 / 18$ & $2 / 6$ \\
\hline Bacteriodes $(\mathrm{n}=52)$ & $33 / 51$ & $12 / 13$ & $16 / 28$ & $7 / 18$ & $3 / 6$ \\
\hline Clostridium $(\mathrm{n}=29)$ & $23 / 51$ & $9 / 13$ & $15 / 28$ & $5 / 18$ & $2 / 6$ \\
\hline Veillonella $(\mathrm{n}=29)$ & $24 / 51$ & $8 / 13$ & $13 / 28$ & $7 / 18$ & $1 / 6$ \\
\hline Eubacterium $(\mathrm{n}=24)$ & $18 / 51$ & $10 / 13$ & $9 / 28$ & $4 / 18$ & $0 / 6$ \\
\hline $\begin{array}{l}\text { Bifidobacterium } \\
(\mathrm{n}=22)\end{array}$ & $15 / 51$ & $4 / 13$ & $5 / 28$ & $6 / 18$ & $1 / 6$ \\
\hline $\begin{array}{l}\text { Actinobacterium } \\
(\mathrm{n}=20)\end{array}$ & $16 / 51$ & $4 / 13$ & $7 / 28$ & $3 / 18$ & $0 / 6$ \\
\hline Enterococcus $(\mathrm{n}=15)$ & $7 / 51$ & $2 / 13$ & $3 / 28$ & $4 / 18$ & $0 / 6$ \\
\hline Fusobacterium $(\mathrm{n}=8)$ & $3 / 51$ & $9 / 13$ & $3 / 28$ & $2 / 18$ & $2 / 6$ \\
\hline
\end{tabular}


Figure 1. Gut Microbiota detected in patients with single etiologies vs co-infections.

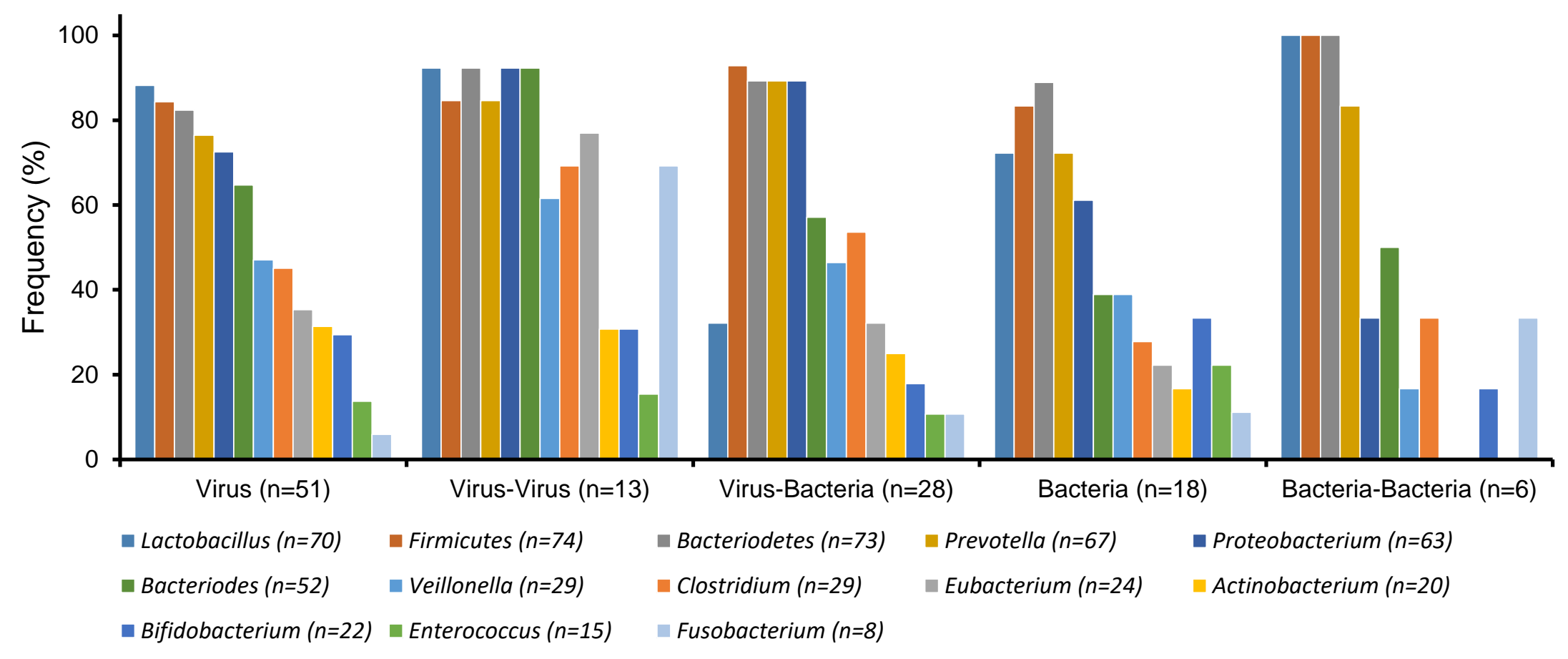


Figure 2. Gut microbiota variations among the different types of breastfeeding in children with acute gastroenteritis

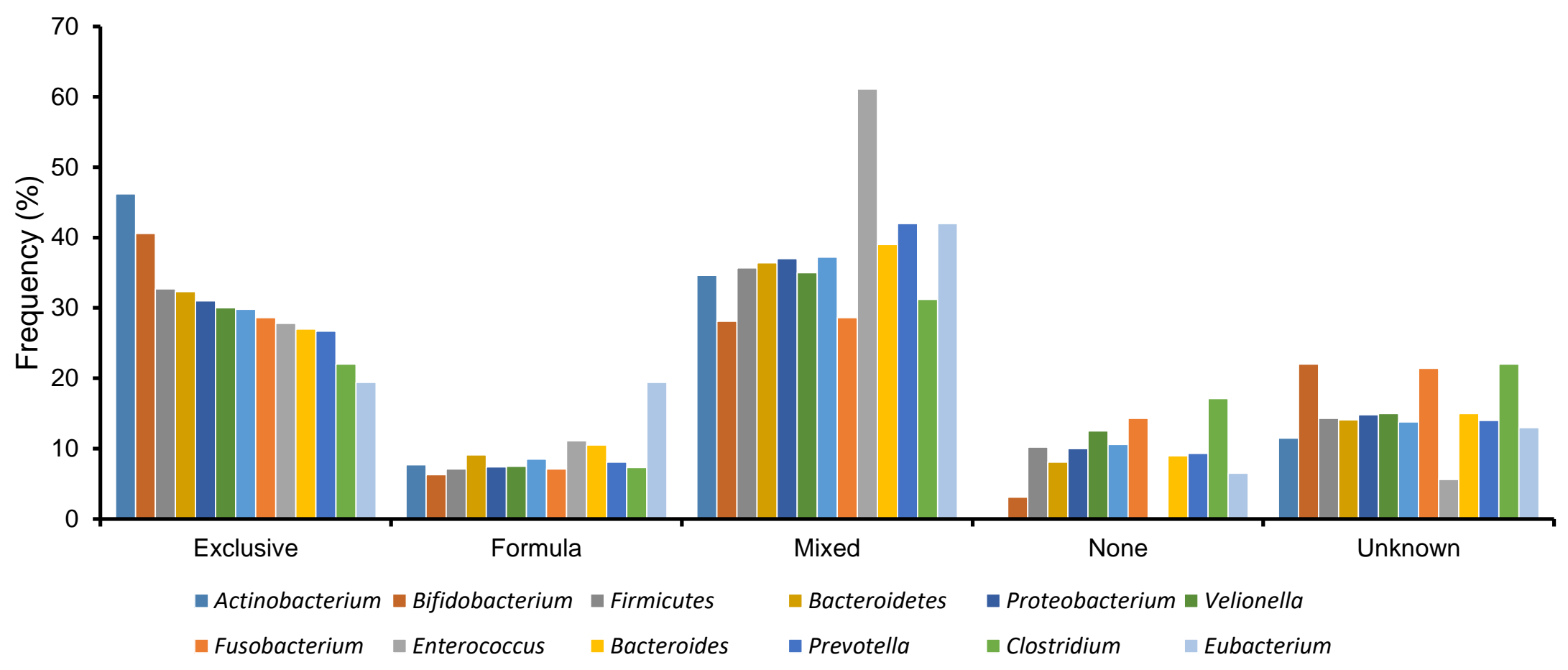




\section{DISCUSSION}

The gut microbiota (GM) is a complex community of microorganisms residing in the human gastrointestinal tract (HGIT). This collection of bacteria, archaea, and eukarya offer benefits to the host strengthening gut integrity, protecting against potential pathogens and regulating host immunity [7-14]. However, alterations in the microbiota composition, also known as dysbiosis, can result in the disruption of these protective mechanisms increasing their risk for infections $[7,8,17]$. This study main objective was to describe the prevalence of 6 common GM bacterial genera and 7 bacterial phyla in stool samples from children under 5 years of age with AIG with different etiologies.

The most common causes of AIG in children are viruses in approximately $70 \%$ of cases, followed by bacteria in 10-20\% [18,19]. Among the viral etiologies, Rotavirus is the most frequent pathogen with different viral strains varying by season and geographies and affecting primarily children under 5 years old [18-20]. Furthermore, in underdeveloped countries, pathogenic bacteria can be the leading cause of AIG being E. coli the most commonly isolated etiology followed by Shigella flexneri $[18,21,22]$. In our population, a viral etiology was isolated in $63.2 \%$ of all samples and bacteria were detected in $54.7 \%$. Rotavirus was the most common etiology detected in $36.8 \%$ (43/117) of our samples, followed by Shigella in 26.5\% (31/117).

Another important point is the dehydration. Clinical signs of it are not usually present until the children have lost at least $5 \%$ of his body weight; thus, determining the degree of dehydration in children can be challenging to clinicians [18]. To assess the hydration status in children with AIG we took into account the clinical findings, the percentage of weight loss, the etiological agent and the performed treatment. In this study, most of the patients 
presented mild (65.8\%) and moderate $(32.5 \%)$ dehydration, such is so the oral rehydration was the most frequent therapy of choice, with only $7.6 \%$ of our patients requiring intravenous rehydration. Furthermore, not surprisingly, Rotavirus, in which mild to moderate dehydration is the most common sign, was the most common etiology in our population.

Undernutrition in children is associated with a reduced microbiota diversity, characterized by a low prevalence of Bacteroidetes and a high number of Proteobacteria. This susceptible population has a higher infection risk for Klebsiella and Escherichia [23-26]. Moreover, a study in Indian found that infections due to Escherichia, Streptococcus, Shigella, Enterobacter, and Veillonella generate are more frequent in children with a malnutrition [23]. In our study, only $14.5 \%$ (17/117) of patients had chronic malnutrition as a risk factor for acute gastroenteritis and only 4 cases of Shigellosis and 3 cases of EAEC were observed. Likewise, Proteobacterium were less common among patient with a bacterial AIG.

Another important point is breastfeeding. Studies have shown that it provides prebiotics and bacterial communities that stabilize the GM during the first year of life, including Bifidobacterium, Lactobacillus and Bacteriodetes [27,28]. This beneficial effect has been reported in breastfed and mixed-fed infants who acquire a greater amount of bacteria from the human milk compared to their counterparts [24]. In our study, most of our patients had mixed feeding (39.3\%), followed by those who received an exclusive breastfeeding $(29.1 \%)$. The GM bacteria in those feeding patterns which included human milk presented a higher frequency of detection specially in Bifidobacterium, Actinobacterium and Enteroccus bacteria. This finding further supports the study of Bäckhed et al [28] who showed that the sole presence of human milk predisposes to greater GM diversity compared to the population who was not breastfed. In addition, we must stand out there are some bacteria who need 
being supported by human milk or formula such as Enterococcus and Actinobacteirum, who were undetectable in people who received none, as we can note in our study.

In our population, the most prevalent microbiota bacteria were Firmicutes (63.2\%) Bacteriodetes (62.4\%), Lactobacillus (59.8\%), Prevotella (57.3\%), Proteobacterium (53.8\%), and Bacteroides (44.4\%). On the other hand, Clostridium (24.8\%), Veillonella (24.8\%), Eubacterium (20.5\%), Bifidobacterium (18.8\%), Actinobacterium (17.1\%), Enterococcus (12.8\%) and Fusobacterium (6.8\%) were the least common detected. These last three can guide us that the mere presence of any etiological agent, whether viral or bacterial, can be disruptive for these GM bacteria. That is why those who can generate any alteration in their homeostasis are, principally, the cytotoxic bacteria such as Shigella and $E$. coli species. Such is so, the low detection of Enterococcus, Bifidobacterium and Fusobacterium was due to the presence of Shigella flexneri and EAEC, however, we shall state that some viral etiologies, such as doble stranded linear DNA viruses, can be dangerous for Enterococcus, specially Adenovirus, who can disturb the intestinal $\mathrm{pH}$ generating an acid one leading to death of Enterococcus who predominantly lives in alkaline $\mathrm{pH}$ [29]. As stated elsewhere, the decrease of GM communities, such as the ones who were absent, are correlated with chronic disease due to the persistent inflammatory state created by dysbiosis [30]. Many of these ones are autoimmune diseases and they are linked to this trend such as Crohn's disease in which the pivot GM finding is the decreased Bifidobacterium and Fusobacterium [31], whereas the Ulcerative Colitis has the same pattern of GM, but with a more predominant decrease of Fusobacterium [32]. On the one hand, there are other contexts, such as Henoch-Schönlein purpura where the keystone is the detection in the Enterococcus who play a role in the pro-inflammatory state [33]. Although our study has used a qualitative assay, we have observed the absence of these GM communities. That why we can also hypothesize that the lack of those specific bacterial communities exerts the pro- 
inflammatory states in chronic diseases and may play a role as protective GM bacteria. However, it is difficult to speculate what these frequencies implies in our patient since this is a novel research field. Nonetheless, based on currently published studies on these microbiota bacteria different hypothesis can be proposed.

Although the human GM contains at least 1000 different species of known bacteria, protective mechanisms against AIG have been described in only a few of them. For example, Bacteroides, which is the most predominant anaerobic bacteria in the HGIT, provide sugar molecules through carbohydrate fermentation which are important in the activation of $\mathrm{T}$ cell-dependent immune response, and the expression of protective proteins from the Paneth cell (defensins and Ang4) [34]. Further bacteria such as Proteobacterium play an important role in the transition from the neonatal to adult microbiota, favouring colonization by obligate anaerobes; which later are replaced by Firmicutes and Bacteroidetes. These bacteria were commonly detected in our patients, with no significant difference in their prevalence across the different etiologies isolated. However, an increased number of Firmicutes and Bacteroidetes in the gut can be used as an indicator of dysbiosis $[35,36]$. Thus, the increased prevalence of them may be a signal of dysbiosis, which lead to the disruption of these protective mechanisms.

Another important bacteria are Lactobacillus, which are a major probiotic factor for other bacteria, as well as a modifier of the cell surface glycan, enhancing the action of Bacteroidetes [14]. Additionally, Lactobacillus serves as a microbiota stabilizer between other communities exchanging DNA traits and other soluble factors [37]. Lactobacillus was common in our patients and some strains, such as Lactobacillus GG, may reduce the duration of diarrhea in AIG [38], playing an important in the treatment. 
On the other hand, there are other bacteria such as Bifidobacterium whose main role is downregulate pro-inflammatory responses in the gut epithelium, while Clostridium spp. providing substrates from products of fermentation acting as an impressive anti-inflammatory by avoiding the activation of the transcription factor, NF-KB $[39,40]$. Both of these bacteria were not predominantly detected in our population.

On the one hand, another anti-inflammatory bacteria, such as Enterococcus, contributes to colonic homeostasis through PPAR $\gamma 1$-induced IL-10 and TGF-B expression and can reduce the severity of infectious diarrhea in children. Furthermore, it is used as a probiotic agent, as well as part of the fecal microbiota transplant along with Lactobacillus casei [41]. As we looked above, Enterococcus was less commonly isolated, especially in patients with Shigellosis which has a high inflammatory destruction of the intestinal barrier. Nevertheless, despite of our results we shall stand out that Enterococus has many types of human gut protection. One of them are the bacteriocins, also known as enterocins. These ones are active against Gram-positive foodborne pathogens such as Lysteria Monocytogenes. There are a wide variety of them. For example, enteroncins DD28 and DD93 have been reported to be active against to MRSA and VRE, and preventing biofilms formation. Another enterocins have shown an antifungal activity through the inhibition of the growth of some mold spores such as duracin in the HGIT. Likewise, the enterocin DD14 was reported being active against Clostridium genera, and can also control Campylobacter spp. and C. perfringens infections. However, it can be controversial for us since our study showed a marked low detection of Enterococcus in patients who coursed under Campylobacter jejuni infection. The last but not least, enterocin M4-5 it is a bacteriocin produced by Enterococcus when there is a disruption of the GM and the epithelium, generating butyrate that induce a significant antiinflammatory effect. This is why the Enterococcus can be used as a probiotic as well as a prophylactic treatment for inflammatory bowel disease [42]. 
Further bacteria that is important for the GM is Actinobacteria phylum who represents the minority of the GM, playing a pivotal role in the development and the maintenance of the gut homeostasis, mainly in the modulation of the gut permeability, metabolism and its role of the gut-brain axis. Its main class called Bifidobacterium, is the main producer of short chain fatty acids (acetate and butyrate). It produces high concentration of acetate that protect the host from the enteropathogenic infections, especially from Shigella and Enterohemorragic E. coli [43]. Moreover, Actinobacterium and Bifidobacterium are involved in the process of transformation of linoleic acid into cojungated linoleic acids, those who have the anti-inflammatory potential and the properties like anti-diabetes, anti-atherosclerosis, etc. On the other hand, a decreased number of Actinobacterium is associated with an enhancement of gut permeability that leads to traslocation of LPS into the serum. This trigger the immune system leading to the diabetes and liver diseases [43]. Finally, dysbiosis and the increased gut permeability are associated with an up-regulation of systemic inflammation through the direct neural communication between the enteric nervous system and the vagus nerve [43].

Finally, Veillonella and Fusobacterium were expected to be less commonly isolated as both have a predilection for oral cavity, working as a bridge organism between early and late colonizers [44], being normal their low detection in our samples.

This study is among the first ones to describe the most important GM bacteria's different prevalences in patients with multiple etiologies of AIG. However, as we have discussed previously it is difficult to hypothesize what these frequencies implies in our patient due to the novelty of this field and the study limitations, especially because of the used qualitative method. 


\section{CONCLUSIONS}

In conclusion, despite the etiology of the infection, the most frequent bacteria identified were Firmicutes, Bacteroidetes, Lactobacillus, Prevotella, and Proteobacterium, while the most affected were Actinobacterium, Enteroccocus and Fusobacterium. However, despite the frequencies, there are some important bacteria which has a crucial role maintaining the integrity of the GM and the enteric epithelium among all described GM bacteria, such as Bacteroidetes, Enterococcus, Bifidobacterium and Actinobacterium, whose main roles are stabilize the GM. Such is so, we can see that the most affected are the ones who promote the homeostasis and the continuity of the intestinal microbiome. Furthermore, despite of being allocated into risk group, including microorganisms harboring virulence factors, Enterococcus acts as a reservoir for dissemination of antibiotic resistance. This is because the broad inhibitory spectra of its bacteriocins make them appropriate candidates to protect the HGIT from high and dangerous to bacterial etiological agents such as $H$. pilory, Salmonella spp., C. difficile, L. monocytogenes, and entero-hemorragic E. coli. Also we have to take into account the Actinobacterium and the Bifidobacterium whose main roles fall in the modulation of gut permeability and the brain axis, both of them play a crucial role when there is a pro-inflammatory state, whether an infection or a systemic disease throughout a high concentration of small chain fatty acids, promoting a protective barrier in the mucosa, and stabilizing the GM along with Bacteroidetes. These data guide us that every GM bacteria has an important role to maintain the homeostasis. Finally, many of these described GM bacteria are used as a probiotic, but what are the requirements that any probiotic must have? Well, this question has 4 important parts that every probiotic must have to. First, every probiotic shall have tolerance to human gastric juice and bile. Second, all of them must be able to adhere to the epithelial surfaces of the HGIT. Third, they should be 
able to protect the GM integrity from gastrointestinal pathogens, and last but not least, they must be able to stabilize and modulate the GM appropriately. For all of above, why does the clinicians prefer to prescribe a single bacteria regimen as a probiotic? After the results of this study, we are able to hypothesize that the current treatment regimens must focus on a symbiotic therapy, which content more gut microbiota bacteria instead of the single regimen, such as Lactobacillus regimens, which are the most used ones in the AIGs, since the bacteria of the intestinal microbiota are distributed in a same way in viral, bacterial gastroenteritis or in various co-infections. In addition, we recommend to perform more studies focusing in the most impaired bacteria in this study such as Enterococcus and Actinobacterium, who play an important role in the pathophysiology of inflammatory and infectious diseases. It can be convenient since it could give rise to future researches being able to carry out works focused on the GM in a global way, leading to a possible change in the treatments, using symbiotics instead of probiotics.

\section{LIMITATIONS}

First, samples were obtained only once during the acute event of gastroenteritis, being important have a pre and post sample to compare the changes in GM. Another limitation is that the microbiota disruption is skewed in certain cases, such as the fact that there are mixed infections of pathogenic microorganisms, which cause an overestimation or underestimation of the final result. Further one is the lack of normal range values to determine if the number of bacteria from the GM we isolated are decreased or augmented. Nonetheless, we tried to compare our findings with GM bacteria known to be more predominant in different regions of the GI tract. Also, an interesting finding, such as the visible reduction of GM bacteria 
among patients with a bacterial infection or the higher number of GM in a patient receiving exclusive or mixed breastfeeding were worth mentioning; however, it is not possible to determine a cause-effect relationship. Finally, the database did not assess fungal neither parasitic gastrointestinal infections. 


\section{REFERENCES}

1. WHO. Diarrhoeal disease. [Internet]. Ginebra. WHO; 2017. [Accessed August 08, 2018; Cited on August 21, 2017] Available at: http://www.who.int/mediacentre/factsheets/fs330/es/

2. Gutiérrez-Castrellón P, Salazar-Lindo E and Polanco Allué I. Guía práctica clínica ibero-latinoamericana sobre el manejo de la gastroenteritis aguda en menores de 5 años: esquemas de hidratación y alimentación. 2014; 80(1): 11-25.

3. Liu L, Oza S, Hogan D, Perin J. Global, regional, and national causes of child mortality in 2000-13, with projections to inform post-2015 priorities: an updated systematic analysis. Lancet. 2015; 385(9966):430-40.

4. Elliot EJ. Acute gastroenteritis in children. BMJ. 2007 Jan 6; 334(7583): 35-40.

5. O’Ryan G, Ashkenazi-Hoffnung L, O’Ryan-Soriano M, Ashkenazi S. Management of acute infectious diarrhea for children living in resource-limited settings. Expert Rev Anti Infect Ther. 2014 May;12(5):621-32.

6. Ordoñez L. Situacion epidemiológica de las enfermedades diarreicas agudas (EDA) en el Peru, SE 05-2018; 27(05) 79-80. Available at: http://www.dge.gob.pe/portal/docs/vigilancia/boletines/2018/05.pdf

7. Van den Elsen L, Poyntz H, Weyrich L and Young W. and Forbes-Blom, E. Embracing the gut microbiota: the new frontier for inflammatory and infectious diseases. Clinical \& Translational Immunology. 2017; 6(1): 125-34.

8. Goulet O. Potential role of the intestinal microbiota in programming health and disease. Nutr Rev. 2015; 73 Suppl 1:32-40. 
9. Petrof EO, Gloor GB, Vanner SJ, and Weese SJ. Stool substitute transplant therapy for the eradication of Clostridium difficile infection: 'RePOOPulating' the gut. Microbiome. 2013 Jan 9;1(1):3

10. Munoz S, Martz S, He S and Noordhof C. Tu1982 Investigating the Therapeutic Potential of Met-1 Probiotic Mixture in an Infectious vs. Chemically-Induced Model of Acute Colitis in Mice. 2013; 144(5): S896

11. Human Microbiome Project C. Structure, function, and diversity of the healthy human microbiome. Nature. 2012; 486:207-214Martz S-LE, McDonald JAK, Sun J, Zhang Y-G,

12. Yhurist-Doutsch S, Arrieta M, Vogt S ND Finlay B. Gastrointestinal MicrobiotaMediated Control of Enteric Pathogens. Annual. Rev. Genet. 2014; 48: 361-82.

13. Tremaroli, V.; Bäckhed, F. Functional interactions between the gut microbiota and host metabolism. Nature. 2012(489): 242-9.

14. Schippa S, Pia-Conte M. Dysbiotic Events in Gut Microbiota: Impact on Human Health. Nutrients. 2014,6(1): 5786-5805.

15. Cornejo-Tapia A, Orellana-Peralta F, Weilg P, Bazan-Mayra J, Cornejo-Pacherres H, Ulloa-Urizar G, Aguilar-Luis MA, Pons MJ, Del Valle Mendoza J. Etiology, epidemiology and clinical characteristics of acute diarrhea in hospitalized children in rural Peru. J Infect Dev Ctries. 2017 Dec 10;11(11):826-832.

16. Murri M, Leiva I, Gomez-Zumaquero JM, Tinahones FJ, Cardona F, Soriguer F, Queipo Ortuño MI. Gut microbiota in children with type 1 diabetes differs from that in healthy children: a case-control study. BMC Med. 2013 Feb 21;11:46.

17. Thursby E, Juge N. Introduction to the human gut microbiota. Biochem J. 2017 Jun 1; 474(11): 1823-1836.

18. Elliot EJ. Acute gastroenteritis in children. BMJ. 2007 Jan 6; 334(7583): 35-40. 
19. Chen S, Ni YH, Chen HL, Chang MH. Microbial etiology of acute gastroenteritis in hospitalized children in Taiwan. J Formos Med Assoc. 2006 Dec;105(12):964-70.

20. Shah M, Odoyo E, Wandera E, Kathiiko C, Bundi M, et al. Burden of Rotavirus and Enteric Bacterial Pathogens among Children under 5 Years of Age Hospitalized with Diarrhea in Suburban and Rural Areas in Kenya. Jpn J Infect Dis. 2017 Jul 24;70(4):442-447

21. Dedwal A, Pol S, Bharadwaj R. Microbial Etiology of Acute Gastroenteritis in Pediatric Patients in Western India. Open Forum Infectious Diseases, Volume 3, Issue suppl_1, 1 December 2016, 1206. Available at: https://doi.org/10.1093/ofid/ofw172.909

22. Kotloff K, Nataro J, Blackwelder W, Nasrin D, Farag T, et al. Burden and aetiology of diarrhoeal disease in infants and young children in developing countries (the Global Enteric Multicenter Study, GEMS): a prospective, case-control study. Lancet. 2013, 382(9888):209-22.

23. Pekmez CT, Dragsted LO, and Brahe LK. Gut microbiota alterations and dietary modulation in childhood malnutrition - The role of short chain fatty acids. Clin Nutr. 2018; 30: 1-16.

24. Monira S et al. Gut microbiota of healthy and malnourished children in Bangladesh. Front Microbiol. 2011; 2: 228.

25. Goday P MBBS. Malnutrition in children in resource-limited countries: Clinical assessment. Post TW, ed. UpToDate. Waltham, MA: UpToDate Inc. http://www.uptodate.com (Accessed on March 31, 2018.)

26. Chiejina M, Samant H. Diarrhea, Viral. [Updated 2017 Dec 5]. In: StatPearls [Internet]. Treasure Island (FL): StatPearls Publishing; 2018 Jan-. Available from: https://www.ncbi.nlm.nih.gov/books/NBK470525/ 
27. Yu Z, Chen C, Kling D, Liu B, et al. The principal fucosylated oligosaccharides of human milk exhibit prebiotic properties on cultured infant microbiota. Glycobiology. $2013 ; 23(2): 169-77$

28. Bäckhed F, Roswall J, Peng Y, Feng Q, et al. Dynamics and Stabilization of the Human Gut Microbiome during the First Year of Life. Cell Host Microbe. 2015; 13;17(5):690-703.

29. Rexroad J, Martin TT, McNeilly D, Godwin S, Middaugh CR. Thermal stability of adenovirus type 2 as a function of pH. J Pharm Sci. 2016. 95(7):1469-79.

30. Scott K, Antoine JM, Midtvedt T, Van Hemert S. Manipulating the gut microbiota to maintain health and treat disease. Microb Ecol Health Dis. 2015; 26:258

31. Kowalska-Duplaga K, Gosiewski T, Kapusta P, Sroka A, et al. Diferences in the intestinal microbiome of healthy children and patients with newly diagnosed Crohn's disease. Sci Rep. 2019 Dec 11;9(1):18880. doi: 10.1038/s41598-019-55290-9.

32. Pittayanon R, Lau JT, Leontiadis GI, Tse F, Yuan Y, et al. Differences in Gut Microbiota in Patients With vs Without Inflammatory Bowel Diseases: a Systematic Review. Gastroenterology. 2019; pii: S0016-5085(19)41893-3.

33. Wang X, Zhang L, Wang Y, Liu X, Zhang H, et al. Gut microbiota dysbiosis is associated with Henoch-Schönlein Purpura in children. Int Immunopharmacol. 2018; $58,1-8$

34. Gosh TS et al. Gut microbiomes of Indian children of varying nutritional status. PLoS One. 2014; 9:e95547.

35. Wexler H. Bacteroides: the good, the bad, and the Nitty.Gritty. Clin Microbiol Rev. 2007; 20(4): 593-621.

36. Shin NR, Whon TW, and Bae JW. Proteobacteria: microbial signature of dysbiosis in gut microbiota. Trends Biotechnol. 2015; 33(9): 496-503. 
37. Ramakrishna B. Role of the gut microbiota in human nutrition and metabolism. JGH. 2013; 28(4): 9-17.

38. Szajewska H, Skórka A, Ruszczyński M, et al. Meta-analysis: Lactobacillus GG for treating acute gastroenteritis in children--updated analysis of randomized controlled trials. Aliment Pharmacol Ther. 2013 Sep;38(5):467-76.

39. Odamaki $\mathrm{T}$ et all. Age-related changes in gut microbiota composition from newborn to centenarian: a cross-sectional study. BMC Microbiology. 2016; 16: 90.

40. Lopetuso L, Scaldferri F, Petito V, Gasbarrini A. Commensal Clostridia: leading players in the maintenance of gut homeostasis. Gut pathog. 2013; 5:23.

41. Dubin C and Pamer E. Enterococci and their interactions with the intestinal microbiome. Microbiol. Spectr. 2014; 5(6): 1-24.

42. Hasna Hanchi, Walid Mottawea, Khaled Sebei and Riadh Hammami.The genus Enterococcus: Between Probiotic Potential and Safety Concerns - An Update. Frontiers in Microbiology. 2018(9): 1791.

43. Binda C, Lopetuso LR, Rizzatti G, Gibiino G, Cennamo V, Gasbarrini A. Actinobacteria: A relevant minority for the maintenance of gut homeostasis. Dig Liver Dis. 2018; 50(5): 421-428.

44. Sun J and Kato I. Gut microbiota, inflammation and colorectal cancer. Genes Dis. 2016; 3(2): 130-143. 